\title{
Correlation between exposure to biomechanical stress and Whiplash Associated Disorders (WAD)
}

\author{
Prof William HM Castro*
}

$\mathrm{O}^{n}$ ne of the most discussed questions in WAD is: can an injury of the cervical spine occur in low velocity collisions? Before this question can be answered, the term "low velocity" and the kind of collisions must first be defined. From the study of MEYER ET AL. (1994) it is known that the speed change due to collision, $\Delta \mathrm{v}$, is a suitable parameter to express the biomechanical stress acting on a person in a car collision. This study also showed that from a biomechanical point of view, a bumper car collision is comparable to a normal car collision. In the case of a rear-end collision, MEYER ET AL. found that the biomechanical stress acting on persons exposed to bumper car collisions $(\Delta \mathrm{v})$ at a fun fair in Germany can be as high as $15 \mathrm{~km} / \mathrm{h}$. In literature, one case could be found of an 8-year-old girl with "whiplash" after being exposed to a bumper car collision at a fun fair (KAMIETH 1990). In the Netherlands, a 13-year survey of persons who were admitted to emergency units of hospitals by the 'Consument en Veiligheid' foundation, showed 14 persons with WAD complaints after being exposed to bumper car collisions at a fun fair. In comparison to the enormous amounts of bumper car collisions, these figures are negligible. With regard to these data, one could argue that low velocity collisions can be defined as those where $\Delta \mathrm{v}$ is below $15 \mathrm{~km} / \mathrm{h}$. However, it should be noted that the kind of collision is important. From the work of BECKE ET AL. (1999) and BECKE AND CASTRO (2000), we know that in side collisions with a $\Delta \mathrm{v}$ of just $3 \mathrm{~km} / \mathrm{h}$, head contact with the side window of the car is possible; it can be expected that in such cases the cervical spine will also be exposed to some biomechanical stress (notice however, that not every head contact is automatically equal to an injury of the cervical spine!). In conclusion, before using expressions like "low velocity collisions", its definition with regard to $\Delta \mathrm{v}$ as well as the kind of collision, has to be discussed. With regard to the most common collisions that causes WAD, rear-end collisions, low velocity collisions can arguably be defined as collisions where $\Delta \mathrm{v}$ is below $15 \mathrm{~km} / \mathrm{h}$ (this is for clarity, and does not mean that those collisions can not cause symptoms; this will be discussed later!).

As a result, with regard to the first defined question, it could be modified as follows: can persons who were exposed to a rear-end collision with a $\Delta \mathrm{v}$ of up to $15 \mathrm{~km} / \mathrm{h}$ (i.e. a low velocity collision) really be injured from an orthopaedical point of view? Before answering this question, some general aspects of WAD should be analysed.
Some of the main complaints people have after a real traffic accident are neck pain, headache, tinnitus and arm problems. Although very often in such cases no injury of the cervical spine can be observed, "whiplash" is almost always the standard diagnosis followed by a treatment program (unfortunately this is often still passive therapy, i.e., rest and/or a cervical collar). It is estimated that in the United States whiplash injuries cost $\$ 4.5$ billion annually (YogANANDAN). The amazing fact, however, is that untill now it is still not known what in fact is a whiplash injury. So actually, treatment and a lot of money is going towards something that we do not understand adequately. In accordance with this lack of knowledge is the large number of unscientific papers in literature. The Quebec Task Force found the research reported in literature to be "seriously deficient" at the World Congress on Whiplash Associated Disorders in Vancouver in 1999. Congress president, Hugh Anton, stated that a lot of whiplash associated disorders (WAD) are based on opinion and dogma, rather than evidence. As an attempt to answer the question mentioned above, CASTRO ET AL. (1997) presented a study in which nineteen volunteers (fourteen men aged 28 to 47 years and five women aged 26 to 37 years) participated in 17 rear-end collisions and three bumper car collisions. An extensive medical examination, including magnetic resonance imaging (MRI) of the cervical spine, was performed 1 to 6 days before, 1 day after, and 4 to 5 weeks after the vehicle crash tests, and in two of the three bumper car crash tests. During the crash tests, the volunteers were completely screened off visually and acoustically, and the muscle tension of the various neck muscles were recorded by surface electromyography. Several parameters (e.g., acceleration, velocity) were measured and a motion analysis was made. The results showed that 1 day after the crash, five volunteers had complaints predominantly consisting of muscle soreness of the cervical spine with no injury signs found on the MRIs. After 4 to 5 weeks, only one volunteer still had complaints. He suffered a reduction of rotation to the left of the cervical spine which lasted for 10 weeks. The motion analysis clearly showed that the whiplash mechanism consists of a translation/extension followed by a flexion of the cervical spine. The "hyperextension" of the cervical spine regularly described in the literature did not occur as this was prevented by the headrest. All of the five volunteers were exposed to a velocity change due to collision $(\Delta \mathrm{v})$ of more than $11 \mathrm{~km} / \mathrm{h}$. The ranges of $\Delta \mathrm{v}$ in this study were $8.7 \mathrm{~km} / \mathrm{h}$ to $14.2 \mathrm{~km} / \mathrm{h}$ (average of $11.4 \mathrm{~km} / \mathrm{h}$ ) for

*Orthopedic Research Institute/Orthopädisches Forschungsinstitut (OFI) Düsseldorf, Hamburg und Münster, Germany

Correspondence: Dr William HM Castro, Orthopädisches Forschungsinstitut (OFI) Düsseldorf, Hamburg und Münster, Hafenstr. 3-5, 48153

Münster, Germany 
vehicle crashes and $8.3 \mathrm{~km} / \mathrm{h}$ to $10.6 \mathrm{~km} / \mathrm{h}$ (average of 9.9 $\mathrm{km} / \mathrm{h}$ ) for bumper car collisions. The ranges of mean acceleration were $2.1 \mathrm{~g}$ to $3.6 \mathrm{~g}$ (average of $2.7 \mathrm{~g}$ ) for the target vehicle and $1.8 \mathrm{~g}$ to $2.6 \mathrm{~g}$ (average of $2.2 \mathrm{~g}$ ) for bumper car collisions.

In contrast to the findings of CASTRO ET AL., BRAULT ET AL. (1998) found in an experimental study with 42 volunteers exposed to a rear-end collision with a $\Delta \mathrm{v}$ of $4 \mathrm{~km} / \mathrm{h}$, that $29 \%$ of the subjects had WAD. When the same persons were exposed to a $\Delta \mathrm{v}$ of $8 \mathrm{~km} / \mathrm{h}$ this percentage increased to $38 \%$. When it is known that a $\Delta v$ of $4 \mathrm{~km} / \mathrm{h}$ is more or less equivalent to a mean vehicle acceleration of $1 \mathrm{~g}$, one has to question why so many of the subjects had complaints after being exposed to a rear-end collision with an acceleration that people are regularly exposed to during several of the activities of daily living.

Considering the results of BRAULT ET AL., CASTRO ET AL. (2001) wanted to find out how many persons would complain of WAD symptoms after being exposed to a collision with no relevant biomechanical stress, i.e., after a placebo collision. In this study, 51 volunteers ( 33 males and 18 females with a mean age of 32.4 years) were recruited through local newspaper advertisements and were exposed to placebo collisions with a negligible acceleration (i.e., mean vehicle acceleration of $0.03 \mathrm{~g}$ ). Prior to the placebo collisions, the history of the participants were taken and physical examinations were performed, including a psychological analysis (four subscales of the Freiburger Personality Inventory (FPI): Life Satisfaction [including job satisfaction and comfort with private life], Tendency of Psychosomatic Disorders, Health Concerns [fear of illness] and Emotional Instability). Immediately after each placebo collision (time T1), a history was taken again and a physical examination was performed. At three days (time T2) and also at four weeks (time T3) after the placebo collision, each subject completed a symptom questionnaire. Data analyses included a determination of the predictive value of psychological data for the presence of symptoms following exposure to a placebo collision. Results showed that at time T1, nine out of 51 participants $(17.6 \%)$ indicated symptoms. Within three days, 10 subjects (19.6\%) had symptoms and within four weeks 5 subjects $(9.8 \%)$ had symptoms. Of the last 5 persons, $2 \mathrm{did}$ not relate these symptoms to the "collision". A discriminate analysis using all four psychological scales from time TO had a $87 \%, 83 \%$ and $92 \%$ power for a correct classification of the subjects as symptomatic or asymptomatic at times T1, T2, and T3, respectively. From the results of this study the authors showed that even though no biomechanical potential for injury exists, almost $20 \%$ of the participants indicated WAD. Such complaints can only be explained by psychological factors. This means that complaints after a low velocity collision can be induced by psychological factors rather than by injury of the cervical spine. The study also reveals why results of a study, such as that of BRAULT ET AL., can not be properly interpreted without a control group subjected to a placebo collision.

The standard rule in orthopedics/traumatology is that an injury can only appear when the biomechanical stress acting on a person is higher than the maximal physiological threshold of that person. What does this mean? On the one hand, an injury can appear when the stress is higher than the physiological maximal threshold of an average normal person. On the other hand, an injury can occur in those persons who are exposed to only a moderate or even low biomechanical stress, but who also have so-called injury-supportive factors. What is meant by those factors? Everyone knows that osteoporosis is an injurysupportive factor for fractures (i.e., in persons with osteoporosis, the amount of stress that causes the fracture can be lower than what is usually necessary to cause a fracture). In WAD, however, it is not the bony but the soft tissue structures that are the region of interest. So the question arises, are there some known injury-supportive factors for the soft tissues of the cervical spine? In daily practice, in literature (WITTENBERG ET AL., 1998), and during scientific meetings, it is often assumed that degenerative changes of the cervical spine make the spine more vulnerable for injuries, i.e., it is discussed that degenerative changes are an injury-supportive factor (at first view this is amazing because one can ask why degenerative bony changes may affect the soft tissues of the spine?). A critical review through the literature will show that this hypothesis is not correct. As one example, the work of MÜNKER ET AL. (1995) can be mentioned. They analyzed 15,000 car accidents and found that the relative amount of neck injuries decreased in persons older than 50 years of age. As a conclusion of the literature review, it can be stated that it is not scientifically proven that the existence of degenerative changes of the cervical spine has to be regarded as an injury-supportive factor. In literature, more arguments can be found against than in favour of this hypothesis. From the point of view of the author, injury-supportive factors for the soft tissues of the cervical spine could be soft tissue diseases or some developmental or acquired deformities of the cervical spine, like segmental fusion (because of the change in biomechanics of the spine). Also the intake of medication like glucocorticoids over a long period of time can change the soft tissue structures in a negative way. So depending on the balance between the biomechanical stress a person is exposed to during the traffic accident and his/her personal threshold, something like a "whiplash-injury" may exist, however, not everyone who says he/she is injured after an accident will really be injured because the biomechanical stress acting on this person can be lower than his/her threshold. For every day practice, when a patient presents after being exposed to such an accident, it should be clear from the result of the "placebo-collision study" that complaints of these persons should not automatically be interpreted as evidence for the existence of an injury of the cervical spine. However, it should not be forgotten that although in such an accident the biomechanical stress may be low, the psychological stress can be very high. The accident victims may quite honestly believe they have been physically injured, even when they have not been injured. The attending doctor should therefore always take the complaints of the accident victims seriously. When objective signs of injury can be excluded, the patient should be treated actively. For IME-practice in persons with a lot of complaints and no objective injury signs, an interdisciplinary approach in which an engineer calculates the range of biomechanical stress acting on the accident victim is recommended, consecutively, a traumatologist or an orthopedic surgeon should look for objective physical injury signs and when necessary, a psychologist should examine the person to look for accident-related psychological reactions. 


\section{REFERENCES}

1. Anton H. Highlights of the World Congress on Whiplash Associated Disorders in Vancouver. The Physical Medicine Review 1999.

2. Becke Mer, Castro WhM, Van Aswegen A, Meyer S. Zur Belastung von Fahrzeuginssassen bei leichten Seitenkollisionen. Verkehrsunfall und Fahrzeugtechnik 1999:293-8.

3. BECKE MER, CASTRO WHM. Zur Belastung von Fahrzeuginssassen bei leichten Seitenkollisionen - Teil II. Verkehrsunfall und Fahrzeugtechnik 2000:225-8.

4. Brault JR, Wheeler JB, Siegmund GP, Brault EJ. Clinical response of human subjects to rear-end automobile collisions. Arch Phys Med Rehabil 1998;79:72-80.

5. Castro WHM, Schilgen M, Meyer S, et al. Do "whiplash injuries" occur in low speed rear impacts? Eur Spine J 1997;6:366-75

6. Castro WHM, Meyer SJ, Becke MER, et AL. No stress - no whiplash? Prevalence of "whiplash" symptoms following exposure to a placebo rear-end collision. Int J Legal Med 2001.
7. Kamieth H. Das Schleudertrauma der Halswirbelsäule: Grundlagen, röntgenologische Differentialdiagnostik und

Röntgenfunktionsdiagnostik. Hippokrates Verlag Stuttgart 1990.

8. Meyer S, Hugemann RE, Weber M. Zur Belastung der HWS durch Auffahrkollisionen. Verkehrsunfall und Fahrzeugtechnik 1994:32:15-21,187-99.

9. MÜNKer H, LANGWIeder K, CHen E, et AL. HWS-

Beschleunigungsverletzungen - eine Analyse von $15.000 \mathrm{Pkw}$-PkwKollisionen. In: Neuroorthopädie 6 (Hrsg.). KÜGELGEN B., Springer-Verlag Berlin Heidelberg 1995:115-33.

10. Spitzer WO, SkOVRON ML, Salmi LR, ET Al. Scientific monograph of the Quebec Task Force on Whiplash-Associated Disorders: redefining "whiplash" and its management. Spine 1995;20(Suppl):2-73.

11. Wittenberg RH, Shea M, Edwards C, ET AL. In-vitroHyperextensionsverletzungen der HWS. Oral presentation at the "46. Jahrestagung der Vereinigung süddeutscher Orthopäden e.V.", Baden-Baden, 1998.

This material was presented at the International Congress on Whiplash Associated Disorders, Berne, Switzerland, March 8 to 10, 2001. The paper appeared originally in the book "Whiplash Associated Disorders" - medical, biomechanical and legal aspects, published by Staempfli Publishers Ltd, Berne 2002. The paper is published in North America in Pain Research $\mathcal{E}$ Management with the permission of Staempfli Publishers Ltd. 


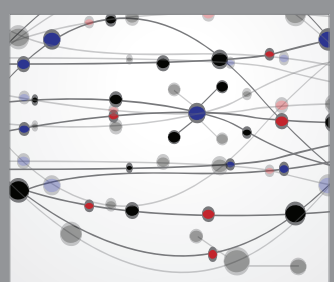

The Scientific World Journal
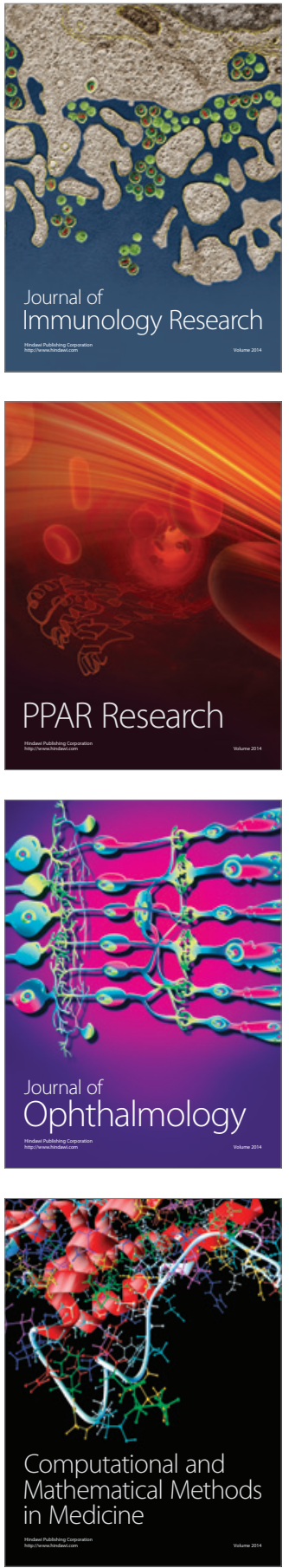

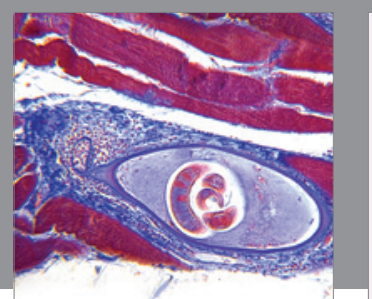

Gastroenterology Research and Practice

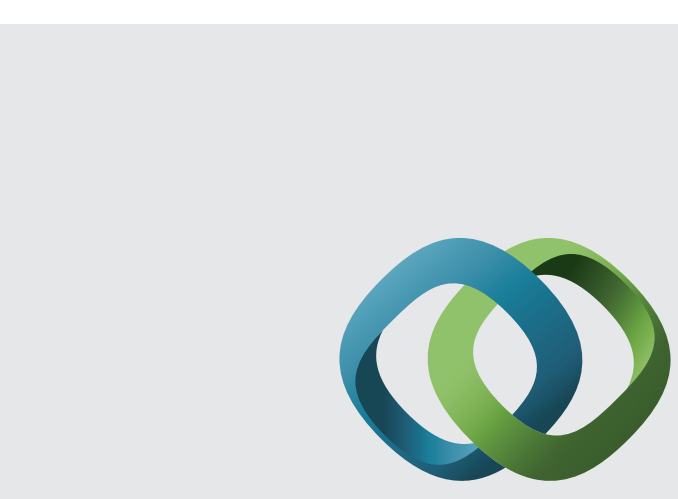

\section{Hindawi}

Submit your manuscripts at

http://www.hindawi.com
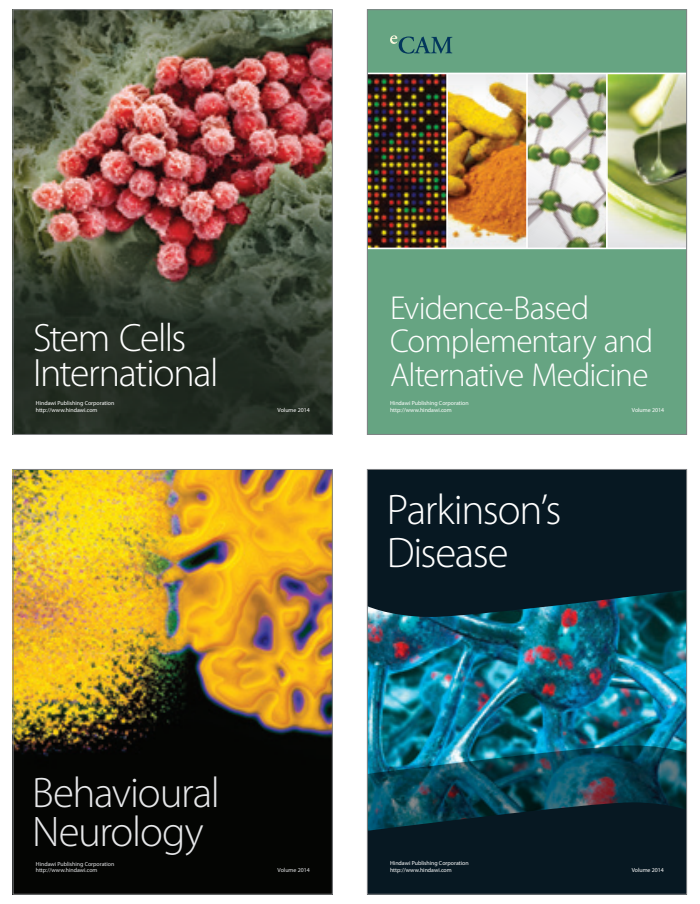
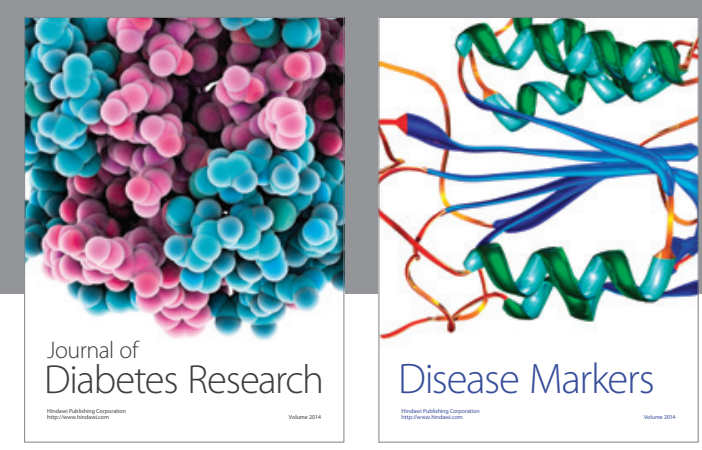

Disease Markers
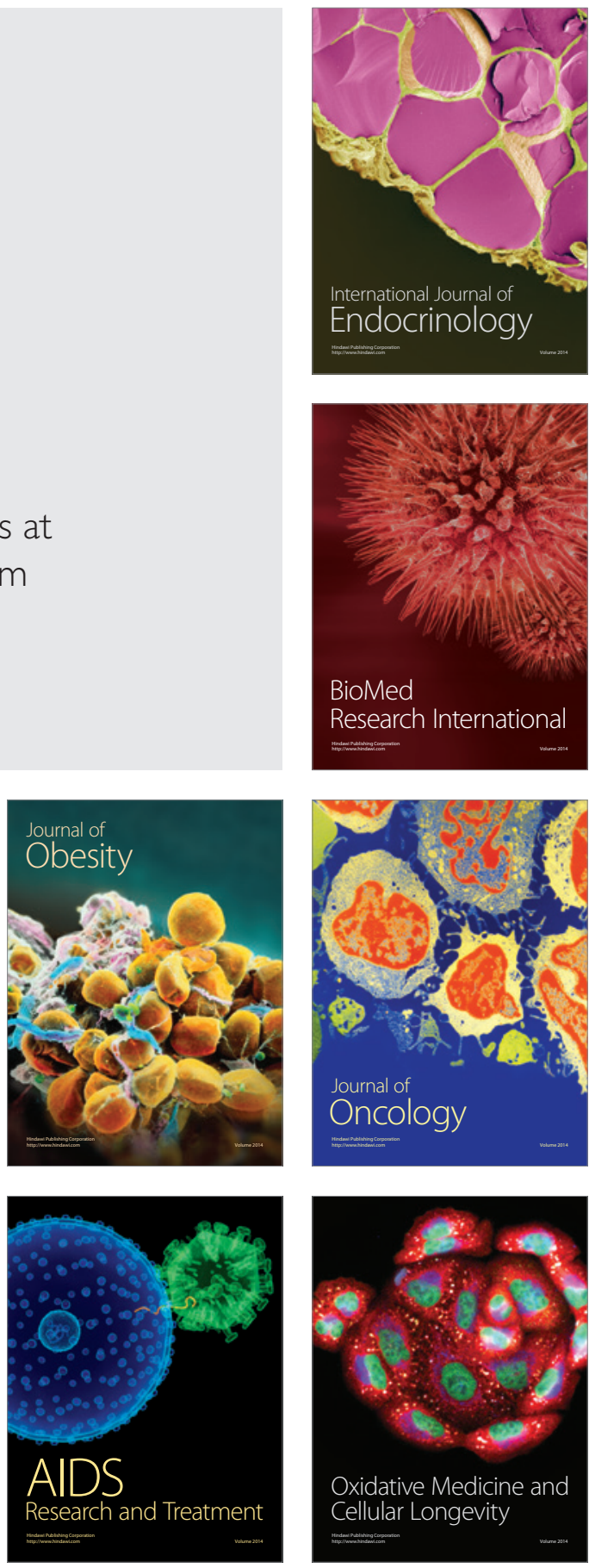